By FELIX REICHMANN

\title{
Hercules and Antaeus
}

\author{
Dr. Reichmann is assistant director of \\ libraries, Cornell University.
}

$\hat{A}^{\mathrm{N}}$ NTAEUS, the son of the goddess of the earth, was a giant of great strength who could not be overcome because he gained new vigor through every contact with the earth. He was slain by Hercules who strangled him in mid-air. Librarianship may not be a giant but it is an intellectual profession of great puissance whose potency and standing derives from the daily and intimate contact with books. The knowledge of books is our source of intellectual energy; cut off from our spiritual mainspring librarianship becomes a mechanical service unit in the lower brackets and at the very best a managerial function in the higher echelons.

There are many forces at work which impede our intimate contact with books, or to use the terminology of the Antaeus fable, strangle librarianship in mid-air. The size of our holdings and the extent of library operations are our great pride but also the agent of conspicuous difficulties. At all times and at all places librarians have described the quality of their institutions in quantitative standards, taking for granted, generally with full justification, that a uniform level of quality was maintained, in the way we compare populations largely only by figures, accepting as our tenet the equality of all human beings. We are recording the number of books in our stacks, the annual volume of acquisition, the amount of processing, the size of our circulation, and the sum of reference questions; proudly we report yearly increase in practically all these figures. However, since we have not been able as yet to develop new methods adequate to cope with this mass production the very bulk of our work converts books into statistical items. The harassed acquisition department places daily purchase requests by the scores, but remains largely unimpressed by the value or prominence of the individual item ordered. The overworked catalog department can pay attention to technical problems only; a rare or otherwise important volume for which a printed Library of Congress card is available will receive less scrutiny than an inconsequential title whose corporate entry poses an interesting catalog problem. The hardpressed circulation department gives books out over the counter by the hundreds and can hardly devote more circumspection to the single title than a clerk in a department store during rush hours. The reference department is so overwhelmed by the flood of requests for information and interlibrary loans that its staff has scarcely the time to get fully acquainted with the reference collection proper. The bulk of our holdings and the daily acquisitions which are all potential tools for reference service remain for the most part unnoticed. The library administrator is entangled in a net of managerial and administrative issues and preoccupied with the problem of the public relations of his library. The growth of the collection looms as a fiscal question or as a storage proposition but paper work, conferences and committee meetings leave no time for the "book."

Moreover, the scope of librarianship as a field of scholarly investigation has been greatly enlarged. Branching out from a predominantly historical study of the single 
book or books either in their subject implications or in the development of their physical forms we now embrace the analysis of the library as a living present-day organism. Libraries are social institutions and cannot serve their purpose well unless we understand their social implications regarding the community of which they form an integral part. Libraries exist for the reader; they are useless unless used. Librarians had to take cognizance of the field of communications and inquired about the reader and his psychological attitudes, his predisposition and behavior. And finally the problem of administration proper had to be considered from all its theoretical aspects. Large libraries are extremely complex and sensitive organisms and cannot be administered on a trial-and-error-basis. It was necessary to re-examine basic assumptions and to re-evaluate them in terms of social and technological developments in order to establish a reliable theory of library administration.

None of these developments can be obliterated, ignored or slighted; they form an essential part of modern librarianship and have greatly enlarged the intellectual horizon of the profession. Moreover, this evolution is not peculiar to librarianship -alone; all intellectual professions must be vigilant less their growth weaken the roots -on which they are based. Lastly this plight is not a characteristic of 1952 ; the perpetual change in all the conditions which determine intellectual life has forced professions again and again to take stock of their expansion and their random adjustments.

However, these considerations do not alter the precarious drift in modern librarianship away from the book. Libraries are composed of books, and the staff entrusted with both the servicing and the administration of the collection will gradually lose in efficiency if librarians remain aloof from the very substance of their profession. Our colleagues in public libraries are generally more book-conscious, because they cannot rely on outside help to do the "bookish work" for them, but conditions in larger university libraries have become rather critical. The position of the university faculty with regard to librarianship as a profession rather than social relations between individuals will influence the morale of the library staff. The attitude of a group does not coincide with the thinking of individuals who compose the group. The individual scholar may be progressive in his own subject field but university faculties are traditionally conservative and have been rather lukewarm to grant librarianship a professional standing. As a matter of fact many faculty members do not quite know where to place us; we neither give courses nor can we be classed with the staff of the central administration. Librarianship as the avocation of a teaching member of the faculty is a respected position but its status, if separated from teaching, is problematical.

There are two main reasons why $\mathrm{li}^{-}$ brarians as a group have not been fully accepted. The complex problem of library records and library administration is of little interest to the average faculty member; it is not understood, is brushed aside as "mechanical work" or "that's your problem" and the difficulties of the intellectual issues involved are grossly underrated. On the other hand it is fully justified that the attention of the faculty should be concentrated on the book holdings and the growth of the collection. Unless the library staff demonstrates that it fully shares this interest it will not be accepted as an equal partner. Unfortunately many librarians fall down in this respect and do not meet even minimum standards either in book 
knowledge or book interest. In many universities the library staff does not actively participate in book selection and is disposed to concentrate on the processing and servicing of the material rather than on accepting any other responsibilities.

This passive position in a question which is of greatest concern to the faculty has raised the question in the minds of many members of the teaching body whether their justified book interests would be safeguarded by a professional librarian. There is general agreement that the ideal librarian combines command of library science with book knowledge. If no person can be found who has both qualities the preference of the faculty will be given to the bookman, under the assumption that it is comparatively easy for a scholar who is trained in the use of books to learn the rules of library administration, whereas the "non-bookman" would face years of hard work in acquiring the necessary book knowledge.

It is an old diversion of mankind to compare the respective difficulties in obtaining given bodies of knowledge. It somewhat reminds me of my own teen-age days when the students of humanistic Gymnasium fought valiant battles with the pupils of the Realschule (which had substituted English and French for Greek and Latin) in the defense and honor of the rigorousness of their particular schools. Neither book knowledge nor the comprehension of library procedures can be "picked up"; both accomplishments are equally essential and both are the results of exacting theoretical training and years of experience.

Without being complacent about our performances it can be stated that the professionally trained librarian meets one of the two qualifications. However, as the duties which we have to discharge gravitate away from bookish matters we do not foster book knowledge which is a requisite for our definition of the librarian. To state that bookman is-or should be-an attribute of librarianship implies the obligation to translate the rather vague term into a workable definition.

The dictionary explanation lacks distinctness. "A bookman knows books and has the knowledge which derives from book reading." (We may note with a smile that the term "bookman" is not always used in a complimentary sense.) What does it mean to "know a book"? It runs all the gamut from complete command of the subject-matter involved (the writer of a scholarly review), to a confused awareness of the physical existence of the title. (See the phrase: "I know the book but I haven't read it yet.") Most knowledge of old books does not imply any familiarity at all with the content of the book. Less than one percent of all bookmen, regardless of their country or scholarly position, who profess to "know" the Hypnerotomachia Poliphili have read the book completely or have the intention of ever reading it. The majority can identify bibliographically "the most beautiful book of the Italian Renaissance" as a production of Aldus in Venice I 499, admire the woodcuts and typographical lay-out, and apprehend its monetary value; a minority is interested in the content of this important literary document and has read an abridgment of the text. Nevertheless, they all use the identical wording: "I know the book."

The attempt to qualify precisely the "knowledge" of a bookman was unsuccessful; to approach the problem with quantitative measurements leads to absurdity. It suffices to pose the question: "How many books must I know to qualify as a bookman?" in order to realize that we are transforming a serious problem into a ridiculous jest.

No definition of "bookman" within the 
framework of librarianship can be meaningful if too closely affiliated with subject specialization. The librarian who confines himself to English literature of the eighteenth century will be the bookman to a few members of the English department but his knowledge will be of little use to a medievalist or a classicist; most probably he will share the arrogant ignorance of most humanists with regard to the sciences, their literature, terminology and bibliographical control. As no human being can "know" all the subject fields represented in a large research library we have to approach the problem from another angle in order to obtain a realistic definition of the librarian as bookman.

The librarian's path to book knowledge is bibliography, bibiography defined as the record of all human endeavors as documented in readable form, with special emphasis on the relation between the author's original manuscript and the text or texts which are at our disposal. Books are commodities, they are produced and sold, and like any other product they owe their effective reality to the combination of two forces, the inventor and the producer. In the consumption of most commodities we are no longer conscious of this characteristic relationship. The personality of the original inventor has been forgotten or it has been fused into an anonymous group of research workers who have continuously improved upon the original conception. The producer (manufacturer) does not fare better; except for some merchandise characterized by their trade marks, his name is of no importance to the customer.

The link between the book and its inventor (author) and producer (publisher.) is plain, perceptible and lasting. No book can exist without an author whose name is permanently connected with it; a publisher is necessary to convert the author's manu- script into a commodity available for use and his identification is compulsory for the characterization of a given copy. Editions are altered and are recognized by publisher's names and dates and in many cases the single copies in one edition show significant variations. Bibliographical analysis is the exact identification of the place a given copy has in the production of a publisher. The bibliographical entity thus determined constitutes the cataloging unit of our records.

In addition to this bibliographical singularity the single copy may be characterized by its general condition, its binding and association value. All commodities can gain additional prominence because of a former association with notable personalities, but it will be mostly a sentimental value. A chair which had been owned by Milton will be highly appreciated but it will contribute nothing towards a better understanding of the poet; however, a book from Milton's library will provide added insight into his personality. All that holds true not only for books printed before 1820 , where copies within one edition may differ widely, but to a large extent for all books in our libraries. Every title is a microcosm in itself, unique in the particular form we have at hand ; the appreciation of this characteristic fact is the psychological prerequisite of the librarian's book knowledge.

An effective approach to our field is the study of the physical appearance of the book in its historical development. But forms without content are empty; the historical investigations on libraries, book manufacturing and book trade must be broadened to a comprehension of the literary activities of mankind, in the sense of Graesse's Literärgeschichte (broader in concept than the usual Literaturgeschichte). Libraries are service institutions and our (Continued on page 34) 
ing microfilm, and it is too early to say what practices will become accepted. In place of definite answers, the following observations may be pertinent:

x. Positive copies of newspaper files can easily be made from negative film. For a paper that is used frequently, positive copies in two or more locations are probably justifiable.

2. Positive copies of extensive files, however, are fairly expensive. For infrequent use some other alternative may be preferable. If libraries spend their funds lavishly for extra copies, there will be less money available for making negative films of papers which should be preserved. The indications are that many libraries are willing to adopt generous lending policies, even to the extent of lending negative film. The fact that film is easily damaged will make it necessary for lending libraries to insist that their film be used only on high-grade reading machines and under strict supervision.

3. A policy of liberal lending of microfilm is an essential part of a cooperative newspaper filming program in which many libraries share the cost of producing the negative film.

\section{The ACRL Buildings Committee}

(Successor to the Cooperative Committee on Library Building Plans)

\section{Presents the Proceedings of the LIBRARY BUILDING PLANS INSTITUTE}

which it sponsored at OHIO STATE UNIVERSITY in APRIL I952

Detailed analysis and criticism by librarians and architects of plans and specifications for seven college and university library buildings ranging in capacity from I00,000 volumes and 350 readers to more than $1,000,000$ volumes and 3500 readers. Special attention given to requirements and implications of modular design.

Eighty pages, including thirty pages of plans. Edited by David Jolly, Assistant Librarian, Northwestern University. Published as ACRL Monograph No. 4. Price \$I.75. Place a standing order to receive all ACRL Monographs automatically as published, and be billed later. Or order No. 4 separately (cost of Nos. I-3, \$I.Io; with No. 4, \$2.85). Address all orders to:

Business Manager, ACRL Monographs

c/o University of Illinois Library

Chicago Undergraduate Division

Chicago I I, Illinois

\section{Hercules and Antaeus}

(Continued from page 25)

studies of the past must be organically linked with an understanding of our immediate and most pressing problem, current bibliographical control.

There can be no doubt that most librarians are vitally interested in books and are painfully aware of their lack in book knowledge. Many recent experiences have shown that the library staff responded en- thusiastically to every opportunity to broaden their knowledge. It is the duty of all of us to make this interest active. In preparing work schedules, in fostering continuous in-service training, in preferment and promotions within the library, book knowledge should be considered an important factor. The entire profession must be conscious at all times that the first half of librarianship is Liber. 